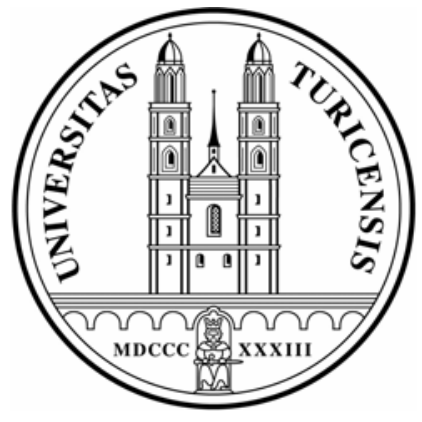

Institute for Empirical Research in Economics

University of Zurich

Working Paper Series

ISSN 1424-0459

Working Paper No. 324

Why Kill Politicians?

A Rational Choice Analysis of Political Assassinations

Bruno S. Frey

May 2007 


\title{
Why Kill Politicians? A Rational Choice Analysis of Political Assassinations
}

\author{
by \\ Bruno S. Frey* \\ University of Zurich \\ and \\ CREMA - Research Center for Economics, Management and the Arts
}

(this version 29 Mai 2007 BSF)

\begin{abstract}
In the course of history a large number of politicians has been assassinated. A rational choice analysis is used to distinguish the expected marginal benefits of killing, and the marginal cost of attacking a politician. The comparative analysis of various equilibria helps us to gain insights into specific historical events.

The analysis suggests that - in addition to well-known security measures - an extension of democracy, a rule by a committee of several politicians, more decentralization via the division of power and federalism, and a strengthening of civil society significantly reduce politicians' probability of being attacked and killed.
\end{abstract}

JEL-Classification: D01, D70, K14, K42, Z10.

Keywords: Rational choice, democracy, dictatorship, assassination, deterrence.

In Schumpeter's (1942) and Downs' (1957) model of a perfectly competitive democracy the two political parties offer the same program. If one party leaves office, the contending party pursues the same program in the median of citizens' preference distribution. Hence, there is no reason to kill a party leader as this would not change policy. No assassinations of politicians in power would be "demanded" and there would exist no need for protection against would-be assassins.

Yet the murder of politicians and other noted persons has long been a favorite topic in the arts. In Shakespeare's "Macbeth", the king is killed by a contender and in Schiller's "Wilhelm Tell", the protagonist as a freedom-loving citizen kills a ruler

\footnotetext{
* Professor of Economics at the University of Zurich and Research Director of CREMA - Center for Research in Economics, Management and the Arts; bsfrey@iew.unizh.ch. I am grateful for most helpful remarks to Christine Benesch, Reiner Eichenberger, Simon Luechinger, Susanne Neckermann, Silke Humbert, Harald Welzer, Isabel Ellenberger and Silja Ang-Tschachtli.
} 
who had been imposed by a foreign power. Famous paintings depict the murder of rulers such as David's “The murdered Marat”(Figure 1).

Figure 1

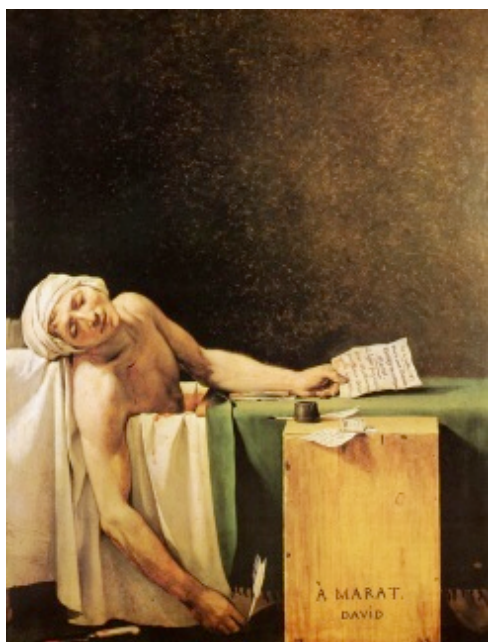

Jacques-Louis David (1748-1825): The murdered Marat (copied from Visipix)

For many people all over the world, President John F. Kennedy's assassination on 22 November 1963 (Figure 2) was a huge shock and an unforgettable event that entered the world's collective memory (Zelizer 1992).

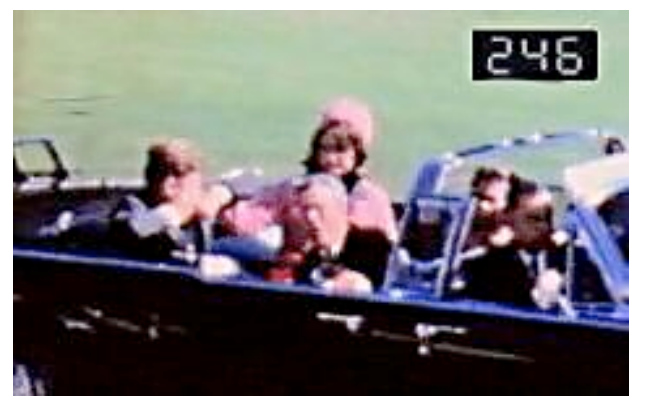

Figure 2

The assassination of President John F. Kennedy (photographed by Zapruder, and copied from Visipix)

The real world is full of murders committed for political reasons ${ }^{1}$. Politicians are killed under many different circumstances, for example by political enemies seeking revenge, such as the first president of the Republic of Kongo, Patrice Lumumba, arranged by his contender Mobutu in 1961, or in 2006 the former Sunnite dictator of Iraq, Saddam Hossein, by the Shiite-Kurdish government. There are also so-called "targeted killings" arranged by other nations (see e.g. Zussman and Zussmann 2006, Statman 2004). The number of political assassinations remains large even if it is

\footnotetext{
${ }^{1}$ A list of assassination of heads of state from 1946 to 2000 is given in the Appendix of Iqbal and Zorn (2006). Statistics from 1875 to 2004 are provided in Jones and Olken (2006). Recent encyclopedic treatises are Lentz (2002) and Sifakis (2001).
} 
restricted to politicians in power (such as kings, presidents or prime ministers) ${ }^{2}$, to successful attempts ${ }^{3}$, and to those undertaken by one or a few persons ${ }^{4}$. This narrower definition will be used in this paper. Famous instances ${ }^{5}$ in classical European antiquity are the assassinations of the Athenian ruler Hypparkos (514 BC), the father of Alexander the Great Phillip II of Macedonia (336 BC), Gajus Julius Caesar (44 BC), and a large number of Roman Emperors ${ }^{6}$. Political assassinations occurred rather rarely in Medieval Europe (though the French kings Henri III and Henry IV were killed in 1589 and 1610, respectively). More recent times saw a great many such murders. Not less than four American presidents were assassinated (Abraham Lincoln 1865, James A. Garfield 1881, William McKinley 1901, and John F. Kennedy 1963). In Russia the four emperors Ivan VI, Peter III, Paul I and Alexander II were murdered within less than 200 years.

The post-war period of the $20^{\text {th }}$ century has also seen a large number of political assassinations creating huge media events. In addition to Kennedy one may, among others, cite in 1973 Luis Carrero Blanco, the Spanish Prime Minister (PM), in 1981 the Egyptian president Anwar as-Sadat, in 1984 the Indian PM Indira Ghandi, in 1986 the Swedish PM Olof Palme, and in 2003 the Serbian PM Zoran Dincic.

These and other assassinations of political rulers were undertaken for many different reasons ranging from political and ideological differences, to attract media attention, to the work of mentally deranged persons. While democratic countries have also been hit, there seems to be a clear prevalence in dictatorial and authoritarian countries. There were, for example, between 1921 and 1945 around 40 assassination attempts

${ }^{2}$ This excludes several recent and well-remembered assassination such as of Robert Kennedy (1968), Martin Luther King(1968), Rajiv Gandhi (1999), or Piet Fortuyn (2002).

${ }^{3}$ There is a large number of thwarted attempts. Counting only significant assassination attempts, there are, for example, the case of American presidents Andrew Jackson, Franklin D. Roosevelt, Harry S. Truman, Gerald Ford and Ronald Reagan. Napoleon III was the object of three attempts within three years (twice in $1855,1858)$.

${ }^{4}$ The Latin word "attentatum" (i.e. attempted crime) which today exists in several languages (e.g.in French "attentat", in Italian "attentato", in Spanish "Attentado" or German "Attentat") but is not used in English, well captures this aspect. Another term sometimes used is "tyrrannicide", meaning the killing of a tyrant. The word assassination refers to the Ismaili Muslim sect Hashshahin, or Assassins, who between the $8^{\text {th }}$ and $14^{\text {th }}$ century terrorized the Abbasid elite by fearlessly executing politically motivated murders of rulers.

${ }^{5}$ Facts on political assassinations have been taken from various sources (especially Iqbal and Zorn 2005, 2006, and Jones and Olken 2006). Various articles in wikipedia on "Assassination", "List of assassins", "List of unsuccessful assassinations", "List of assassinated people", "List of people who survived assassination attempts", "List of assassinations by car bombing", "List of assassinated anticolonial leaders" were also useful; the information reported was checked.

${ }^{6}$ To name a few: Caligula (41AD), Claudius (54), Vitellius (69) Galba (69), Domitian (96), Commodus (192), Didius Julianus (193), Geta (212), Caracalla (217), Elagabal (222), Maximinus Thrax (238), Pupenius (238), Balbinus (238), Volasianus (253), Galeus (253). 
against Hitler ${ }^{7}$, the most notable being in 1933 by Kurt Lutter, in 1939 by Johannes Georg Elser, in 1941 by Erwin von Witzleben, in 1943 by Henning von Treskow and in 1944 by Claus Schenk Graf von Stauffenberg. This will indeed be the central hypothesis in this paper: The more democratic a country, the less political assassinations. Conversely, there is a high "demand" to kill rulers who impose their own will on the population. But clearly, this hypothesis is insufficient as the assassinations of several American presidents and of the Swedish Prime Minister show.

The assassination of rulers and other politicians has been extensively treated in the historical literature, e.g. Hudson 2000, Demandt 2000, Kellerhoff 2003, Uthmann 2004. There is a substantial literature on the assassination of specific politicians (e.g. Woolf 2006 on Caesar, Warren et al. 1964 on John F. Kennedy, or Bondeson 2005 on Olof Palme). It is, of course, a central issue in criminology (e.g. Siegel 2005, 2007, Adler, Mueller and Laufer 2006, Schmalleger 2004). In the social sciences the issue has received some limited attention in sociology (e.g. Wilkinson 1976) and political science (e.g. Feierabend, Feierabend, Nesvold and Jaggar 1971, Laucella 1999, Barkan 2005, and most importantly Iqbal and Zorn 2005, 2006). There is also a specialized "assassination science" (e.g. Fetzer 2000). I am aware of only very few contributions in economics directly dealing with political assassinations (Zussman and Zussman 2006, Jones and Olken 2006) but the economics of crime (e.g. Becker 1968, 1974) and of terrorism (e.g. Enders and Sandler 2006, Frey 2004) are clearly relevant.

This paper uses the rational choice approach to gain insights into the occurrence of political assassinations by distinguishing between the "demand" for killing politicians, and the countermeasures adopted by the possible victims ("supply"). The next section develops a simple model of the demand and supply of the killing of politicians, and determines the equilibrium number of attacks. Section II presents various applications of the model to demonstrate its usefulness. Policy proposals to fight against political assassinations are discussed in section III, and section IV concludes.

\section{A Simple Model of Political Assassinations}

The model is based on the economic theory of crime initially developed by Becker $(1968,1974)$, and since then extended and empirically tested (see e.g. Alper and Hellmann 2006, Cameron 1988). The central idea is that there are two parties involved: there is a "demand" for committing a crime exerted by persons who expect to derive a profit thereof, and there is a "supply" in the sense that possible victims (here the politicians) are able to influence the extent to which they are subjected to an attack. Both actors have options available between which they rationally decide ${ }^{8}$ in

\footnotetext{
${ }^{7}$ Duffy and Ricci (1992), Hamerow (1997), Gisevius (1998).

${ }^{8}$ Non-rational elements may exist but they are of lesser importance than suggested by many observers who attribute a large share of crime, including political assassinations, to irrationality. Nevertheless, for instance "over-optimism" (Weinstein 1980) may well apply to some politicians who believe that they are invulnerable. An example is Hitler who narrowly escaped several assassination attempts and attributed this to "Gottes Fügung" (the will of God). Interestingly enough, his security
} 
order to maximize their utility. A second critical element of the economic theory of crime is that the observed number of crimes committed is the outcome of the interaction of demand and supply, i.e. the equilibrium.

There are many different motivations by would-be assassins to attack a politician (subsection A). The countermeasures are not only bodyguards but also material measures (subsection B). The equilibrium probability of an assassination (always including unsuccessful attempts) and its comparative static properties are discussed in subsection $\mathrm{C}$.

\section{A. The Demand to Assassinate Politicians}

Four different motivations can be distinguished:

1. Achieve Political Change.

This is the major incentive to kill a ruler who pursues a disliked or hated policy. Friedrich Schiller's drama "Wilhelm Tell" deals with a classical instance of this desire, as well as many other dramatic works. The more dictatorial a ruler is, i.e. the more he or she pursues his own will and disregards the will of the population, and oppresses them, the greater is the benefit gained by killing him or her. In contrast, in a democracy this incentive is weak because the policies are sanctioned by an elected parliament, or in some cases even by a popular vote. This forces the rulers to stay close to the preferences of the citizens.

An extreme case represents the model of perfectly competitive democracy by Schumpeter (1942) and Downs (1957) where in order to survive in elections, the two parties must converge to the median of the distribution of voters' preferences. A politician cannot diverge from this position and has to exactly follow the political wishes of the median voter. In this political model of spatial equilibrium there is no demand to kill a politician because the would-be murderer is aware that this does not change the policy pursued at all. Hence there is no incentive for political assassination. It follows that the politicians have no reason to protect themselves, and no politicians will be killed.

The model of pure democracy is strongly simplified but captures a core element of democracy. In a less than perfect democracy - which is certainly the ones observed in reality - additional factors significantly influence the incentive to kill politicians. They all affect the probability of achieving the political change desired by the assassin:

(1) The expected effect on policy is larger when there is one politician in charge than if the policy is determined by a committee of (equal) politicians. This person, it may be a king, a president or a prime minister, plays a prominent role and has some discretionary room to act according to his or her preferences. He or she therefore becomes the object of dislike or hatred by a number of individuals some of which may exert a demand for killing the ruler.

(2) The expected effect on policy is also larger when there is no well-determined succession rule. In that case, the assassination of the ruler provokes a power struggle possibly resulting in a change of policy.

(3) In a centralized state the ruler has more power than in a governmental system with several decision makers. In a country with an extensive division of power

precautions were increasingly stepped up (Hoffmann 1980) so that revealed behavior speaks a different language. 
between the legislature, the executive and the judiciary, as well as between the central and sub-central units (states, provinces, communes) there is a lower incentive to kill politicians as the effect on policy must be expected to be smaller.

(4) The more independent decision makers there are in a society the lower is the expected benefit of killing the government leader because his or her power is smaller. In contrast, in a centrally planned economy, and in a society without well-developed civil units (such as independent trade unions, churches and private clubs) there is a stronger incentive to kill the ruler.

(5) The more fractionalized a society, i.e. the more distinctive ethnicities and religions there are, the more their interests differ, and the more aggressive they are, the more difficult it is for a ruler to satisfy their preferences, and the more likely he or she will be attacked.

(6) A strong international engagement of a country extends the borders of influence of national politicians and therewith makes the ruler more involved in fractional strife. As a result the demand to assassinate the ruler is larger.

(7) The more developed the media are, the stronger is the attention directed to the ruler. An important part of any dictator's policy is to use the media to his or her advantage (see Glaeser 2006). Hitler was one of the first who fully exploited this possibility (skillfully managed by Goebbels, see e.g. Fest 1963, Kershaw 2000); contemporary dictatorships do the same, sometimes to a ridiculous extent (as in the case of Saparmurat Niyazov, President of Turkmenistan 1985-2006, or Kim Jong-il in North Korea). The downside for the dictator's personality cult is that much attention is concentrated on his person, making him or her the object of aggression (e.g Reiner 2002).

\section{Produce Chaos}

Persons may have an incentive to kill a politician to create chaos, independent of whether the ruling politician pursues the will of the population. This has been the avowed goal of some revolutionaries of the $1960 \mathrm{~s}^{9}$. However, the probability that a political assassination leads to chaos is much smaller in a democracy than in a more authoritarian system because the succession rules are clearly determined. Therefore the demand for killing politicians depends on similar factors as for attacker directly aspiring a change of policy.

\section{Seek Media Attention}

There are would-be assassins who by killing a ruler want to attract the attention of the media; they are not interested in the consequences on politics. With a free press, the attention gained typically is larger than with the media in an authoritarian system where the news may even be oppressed in order for the political class to cling to power. A recent example is the sudden death of the dictatorial ruler of Turkmenistan, Niyazov. It was rumored that he was poisoned but whether this is true remains unknown as the media are fully controlled. In contrast, in a country with free media such rumors cannot be suppressed which raises the media attention attained by a

\footnotetext{
${ }^{9}$ It is debatable whether they meet the conditions set above for a political assassination as these revolutionaries were often terrorist groups (such as the German RAF, the Italian Brigate Rosse, or the French Action Direct) and not one or a few individual attackers (see e.g. Frey 2004).
} 
political assassination. There may also be an imitation effect induced by the large media attention (Reiner 2002, Christensen 2004).

\section{Deranged People}

Some would-be killers are attracted by prominent politicians and have an inner drive to kill them, irrespective of how these politicians act and irrespective of the response in the media ${ }^{10}$. An example is John Hinckley who gravely wounded President Ronald Reagan. Hinckley was subsequently determined to have serious psychological problems. He publicly stated that his intention was top get the attention of actress Jody Foster rather than to make any political or ideological statement ${ }^{11}$. These cases can be considered to be (high level) random events.

\section{B. The Supply Side: Protection Against Assassination}

The better a politician is protected against would-be killers the larger are the cost to the attacker.

There are many different countermeasures against political assassinations. It is useful to distinguish between personal and material approaches.

\section{Bodyguards}

In history there are prominent examples of organizations established to protect politicians ${ }^{12}$. One of the earliest and best known is the Praetorian Guard ("Praetoriani") used by the Roman emperors. It exists at least back to the Scipio family and existed until $275 \mathrm{AD}$ when it was dissolved by Constantine I. Its size varied over time. Under the first emperor Augustus it was already quite large, consisting of 9 cohorts with 500 to 1,000 men each. After Augustus the praetorians started to meddle in political affairs. Instead of protecting emperors, they often killed them, examples being Claudius (54 AD), Galba (69), Vitellius (69), Pertinax (193), Caracalla (217), or Elagabalus (222).

The Janissaries formed the Ottoman sultan's household troop and bodyguard. It originated in the $14^{\text {th }}$ century and was abolished four hundred years later (1826) by

${ }^{10}$ There is a considerable psychological and medical literature devoted to these cases. For example, Fine and Vossekuil (1999) estimate that in the United States about 25\% of the actual attackers were found to be delusional, a figure that rose to $60 \%$ with 'near-lethal approachers'. They also estimate that around $2 / 3 \mathrm{rds}$ had previously been arrested for (not necessarily related) offenses, that around $44 \%$ had a history of serious depression, and 39\% a history of substance abuse. These studies thus tend to attribute a large part of all political assassinations to deranged persons. See the critical discussion in Iqbal and Zorn 2005, p. 2.

${ }^{11}$ Prominent persons always run the risk of being attacked on these grounds.

Examples are the Beatle John Lennon in 1980 or the film director, writer and art critic Theo van Gogh in 2004. Unsuccessful assassination attempts were suffered e.g. in 1993 by tennis player Monica Seles who was stabbed by a Steffi Graf fan when she played in Hamburg.

${ }^{12}$ See e.g. Melanson and Stevens (2005), Beyer (2003), DiJulius (2003). The following articles in wikipedia proved helpful to get a first overview: "Bodyguard", "Praetorian Guard", "Janissary", "Imperial Guard", "United States Secret Service", "Royalty and Diplomatic Protection Department". 
Sultan Mahmud II. Its full strength varies widely. In 1475, for example, it counted 6,000 men, in the $18^{\text {th }}$ century 113,000 men (Nicolle1995). As the praetorians, the Janissaries meddled heavily in politics and also killed rulers they were supposed to protect. Thus, they assassinated Sultan Osman II in 1622.

The Garde Impériale was established in 1799 to protect the French consuls but gained prominence under Emperor Napoléon. It consisted of the most prominent Old Guard, the Middle and the Young Guard. In 1804 it counted 8,000 men but with the invasion of Russia in 1812 it comprised more than 100,000 men. Their last stand was at Waterloo where they retreated despite their motto "La Garde meurt et ne se rend pas".

Hitler's bodyguard considered itself as the $20^{\text {th }}$ century equivalents of the praetorians (but they were loyal to the Führer until the very end of WWII). The Schutzstaffel SS (Höhne 1979, Graber 1982) was established in 1920 as a personal guard for Hitler but was initially part of the Schutzabteilung SA. With the execution of the leadership of the SA in June 1934 ("Night of the Long Knives") it became independent. Until 1929 it numbered no more than 280 personnel, but under the leadership of Heinrich Himmler it grew to 52,000 men in 1932, by the beginning of the war to 250,000 men, and during the War comprised 38 divisions. Hitler's personal security (see Hoffmann 1980) was, of course, a smaller unit. In 1934 it was the Leibstandarte SS Adolf Hitler (LSSAH), but when this unit engaged as part of the Waffen-SS in the War, Hitler's personal security was entrusted to the Reichssicherheitsdienst RSD.

Today's most prominent bodyguard is in the United States. It has been designed to protect the president and comprises 2,100 plainclothes special agents (usually in conservative business suits, sunglasses and communication earpieces), a Uniformed Division of 1,200 persons and 1,700 technical and administrative employees ${ }^{13}$. The corresponding unit in the United Kingdom is called Royalty and Diplomatic Protection Department and in Russia the Federal Protective Service (Deriabin 1984, Deriabin and Bagley 1990). The latter is estimated to count more than 30,000 uniformed personnel plus several thousand plainclothes agents. The Presidential Security Service protects the president of Russia. The bodyguards in developing countries may sometimes be disloyal. A famous case is the assassination in 1984 of the Indian Prime Minister Indira Gandhi by two of her Sikh bodyguards (Frank 2002, Sarin 1990, Dilip and Ashok 1985).

The discussion of the various bodyguards makes clear that it is impossible to get any clear quantitative notion of their size. This is not only due to the fact that much is secret but also that they perform many different tasks in addition to protecting the ruling politician. A common feature is, however, that the bodyguard has a strong tendency to grow in leap and bounds, and that the strict task of protecting the ruler is transferred to a smaller specialized unit. Its growth does not necessarily mean that the ruler is better protected because its large number and importance give them the possibility to meddle in politics, and even to seize power itself.

\footnotetext{
${ }^{13}$ The American Secret Service also investigates a wide variety of financial fraud crimes and identity thefts and provides forensic assistance for some local crimes. Not all of the 5,000 Secret Service agents are directly involved with protecting the president.
} 


\section{Material Counter-measures}

There are many different possibilities to raise the costs of attacking a politician. The most important are:

- Clearing large areas, for instance shutting down entire sections of cities and roads, as well as restricted access to buildings;

- Armored cars of which the best known is the "Popemobil" with its bulletproof glass;

- Bomb and weapon detectors;

- Bullet proof vests;

- Body double; or

- Going into seclusion.

These counter-measures are of different effectiveness depending on circumstances, and entail different costs on the person to be protected. They all serve to make an attack more difficult, raising the cost of attempting to assassinate a politician.

\section{Equilibrium}

Following the normal assumptions in rational choice theory, the marginal benefit of killing a politician is taken to decrease, and the marginal cost to increase with the number of attacks. The equilibrium probability of an assassination corresponds to the observed incidence of the killing of politicians.

\section{Equilibrium of political assassinatins}

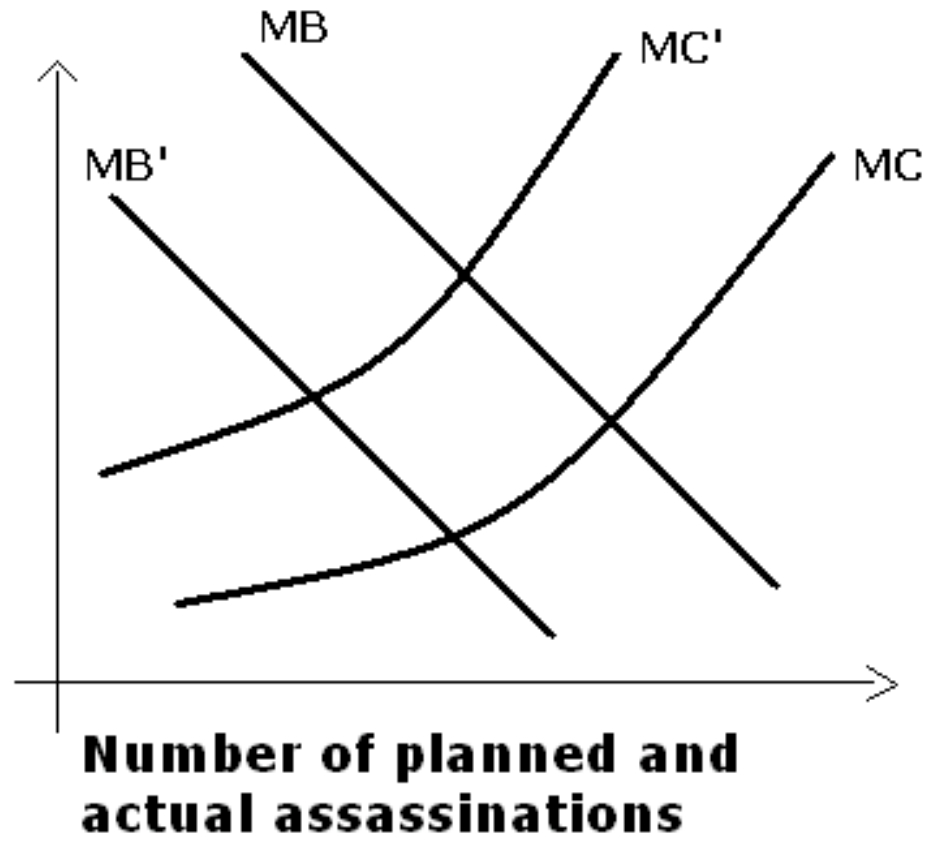

Fig. 3. Demand and Supply of Political Assassinations 
Figure 3 shows the comparative static results of various types of exogenous changes:

- When the marginal curve showing the expected cost of killing a politician shifts upwards for the attacker, the probability of being a target falls. This upward shift may be due to a variety of factors such as an easier access of the ruler to the resources useable for protection. Even if the monetary expenditures for security rise and the marginal costs at a given probability of attack are higher, the total sum expended need not necessarily be. If possible attackers react strongly (i.e. the demand for killing politicians is price elastic), total expenditures fall. In contrast, when would-be attackers are difficult to deter by increased security expenditures, total security outlays rise ${ }^{14}$.

- When the marginal benefits of assassinating a politician shift downwards, the probability of being an assassination target falls. A major reason for such a shift is due to more democratic governance which lowers the incentives to seek a policy change by exerting force. In the extreme case of moving to a pure democracy of the Schumpeter-Downs type, the marginal benefit curve shifts to the origin, and there will not be any political assassinations.

- Exogenous changes in the seven institutional demand factors discussed above lead to a shift in the marginal benefit curve. The benefit curve shifts down resulting in less political assassination if decision-making moves from personal rule to a committee of equals; there is a better defined succession rule; political and social decentralization are intensified, society is less fractionalized with respect to race, ethnicity and religion, international engagement is reduced, and the media are of lesser importance.

- Exogenous changes in the means of protection shift the marginal cost curve to attackers. If exogenous technical progress raises the possibility to effectively protect rulers rather than attack them, the marginal cost curve shifts downwards, resulting in less political assassinations. The same holds if due to an institutional change, more funds become available for security purposes.

- When the freedom of the media is curtailed, the marginal benefits of attacking shifts downwards because an assassination is less likely to get the hoped for attention in the media. This lowers the equilibrium probability of politicians killed

\section{Applications}

Ideally, the propositions derived from the model of political assassinations should be tested econometrically. However, this approach involves systematic problems in the case at hand.

A major difficulty is the data required for econometric studies. What would be needed are reliable data not only on attempted and successful assassination attacks but also on the demand to kill politicians. While the data collected and used by Iqbal and Zorn $(2005,2006)$ and by Jones and Olken (2006) constitute a great advance, serious restrictions on the data considered are imposed. Thus, Jones and Olken (2006: 6-7) only look at assassinations and assassination attempts directed at the national leader

\footnotetext{
${ }^{14}$ This paper focuses on monetary expenditures for protecting the ruler. Frey (2007) considers also the non-monetary costs imposed on the population by, for example, closing down streets and sealing off parts of cities.
} 
who is defined to be "the most powerful political figure in each country at each point of time", a classification which is often debatable ${ }^{15}$. They also exclude coups d'états where the individual or a group of killers try to seize the power for themselves. It is often unknown, or remains hidden on purpose, whether an attack is undertaken by one or a few persons on their own account, or whether there is a large group hired by a foreign country ${ }^{16}$. They moreover only look at "serious" attempts, a classification which may, of course, be interpreted in different ways. Assassination attempts in which the weapon was not discharged, and thus the assassination attempt thwarted, are not considered. Many aspects connected with political murders are either unknown or uncertain, or for political reasons remain undisclosed.

It is important to see that in the case of political assassinations the data are not objective but are systematically manipulated by the persons and organizations involved. This applies in particular to thwarted assassination attempts. The security services often have an interest in publicizing- or even in inventing - thwarted attempts in order to emphasize their importance, and to therewith get more prestige, political importance and funds. Under different circumstances, the security services may have an interest in suppressing the publication of such events because they fear an imitation effect. Such manipulation is easier in dictatorships and in countries with controlled media than in democratic countries. This means that when political assassinations for a large number of different countries (as done by Iqbal and Zorn 2005, 2006 and Jones and Olken 2006) are used some of the data are more unreliable than others. This creates a special problem because political assassinations seem to occur more often in authoritarian developing than in democratic developed economies ${ }^{17}$.

Such manipulation of data is a general phenomenon when the data matter in the political process. For instance, misrepresentation has proved to be a problem for GNP and other economic indicators declared to be goals of government activity. As the rate of unemployment has become a politically important indicator, governments have started to influence it in order to suggest a better picture of the state of the labor market than is true in reality. Thus, persons long unemployed are defined to no longer belong to the work force and therewith do no longer raise the official rate of unemployment. It is also well known that the measure of budget deficit has been strongly manipulated by some European countries when the rules for entering the European Monetary Union required budget deficits not to exceed three percent of GDP and the public debt not to exceed sixty percent of GDP (see, e.g., Forte 2001; Von Hagen and Wolff 2004). Such distortions of indicators were so widespread that

\footnotetext{
${ }^{15}$ It also excludes some important political assassinations as Robert Kennedy (presidential candidate) in 1968, Rajiv Gandhi in 1991 (former Indian Prime Minister) or of Archduke Franz Ferdinand (whose murder sparked WWI) in 1914, not to speak of such noted political figures as Martin Luther King (civil rights activist) in 1968.

${ }^{16}$ It is known, for example, that the US Central Intelligence Agency undertook several assassination attempts against Fidel Castro (CIA 1967). This would classify as a "political assassination attempt" in the more general sense used in this paper because the purpose was to bring about a change in policy. But in many cases such efforts remain undisclosed.

${ }^{17}$ At least if the number of attempted and actual assassinations is considered (as done by Iqbal and Zorn 2005, 2006 and Jones and Olken 2006). But it cannot be excluded that the number of desired and deterred assassinations attempts has a different relation to the data actually used in some of the countries than in others.
} 
observers stated that "[...] the determining factor for achieving membership of the planned European Monetary Union (EMU) seems to rely on widespread use of publicsector creative accounting measures" (Dafflon and Rossi 1999: 59-60). In the case of political assassinations the incentives to misrepresent the facts seem to be even stronger than in the cases just mentioned. As a result, the available data tend to be seriously biased but it is not necessarily known in which direction.

A cross-sectional analysis cannot solve the causality issues involved. It cannot, for example, be excluded that a high occurrence of political assassinations leads to more authoritarian political structures (people demand a "strong man" to establish security). Under these circumstances it is not possible to say whether authoritarian conditions lead to more political assassinations, or whether political assassinations lead to more authoritarian conditions, or both. A panel data analysis would be helpful but is faced with even more data problems because its quality may vary in unknown ways over time.

Econometric research on political assassinations is certainly desirable but faces great difficulties. Existing data allow at best testing partial aspects. In order to get additional empirical insights it is useful to go beyond standard econometric methods.

This section seeks to demonstrate that the simple equilibrium model of assassinations developed helps us to better understand political assassinations occurring in history. Five rulers in specific countries and periods are discussed. They serve to illustrate the factors working on the demand and supply side of political assassinations. As far as possible, only one major determinant is varied moving from one case to the next ${ }^{18}$. The discussion moves from a well-defined ruler in an extreme dictatorship (Hitler Germany); to a well-defined ruler in an well-established democracy with a homogenous population (Sweden); to a well-defined ruler in a well-established democracy with diverse and aggressive factions (United States); to a well-defined ruler in a newly established democracy with diverse and aggressive ethnicities (India); to a weakly defined ruler in an old-established democracy with diverse but nonaggressive ethnicities (Switzerland)

\section{Nazi-Germany}

Between 1933 and 1945, Adolf Hitler was the absolute and well-identified dictator (the Führer) of Germany, suppressing, and annihilating millions of persons (see e.g. Broszat 1960, Fest 1963, Steinert 1991, Kershaw 2000). The expected marginal benefit of killing him was extremely high as such an act promised to greatly change policy as it was formulated and ordered by the Führer. Moreover, his rule was based on a centralization of all power into his hands. Thus, his word was law, and he could freely intervene into all court decisions. Together with the destruction of the division of power, federalism was totally undermined. A civil society no longer existed as there were no longer any independent trade unions, churches, universities or private clubs. With the annexation and occupation of foreign lands before and during the War fractionalization strongly increased. All these institutional factors increased the marginal benefits of killing him.

\footnotetext{
${ }^{18}$ This is, of course, not fully possible because the rulers, countries and periods differ in such a great number of respects that it is impossible to control for all of them. The analysis is informed by the technique of "analytic narratives" championed by Bates et al (1998). See also Rodrik (2003).
} 
At least in the beginning years of his dictatorship, the security precautions were quite weak (see Hoffmann 1980 for an extensive account). Over the course of time they were stepped up, especially after the $20^{\text {th }}$ of July 1944 when Count Stauffenberg tried to kill him at his headquarters at the Wolfschanze near Rastenburg. The marginal costs for an attacker (especially if he or she was ready to commit suicide) were relatively low in the early period.

According to our model, the combination of expected very high marginal benefits, and relatively low costs for an attacker suggests that at the beginning of his rule, many assassination attempts were undertaken against Hitler. Indeed, there were around forty of them ${ }^{19}$. In many cases he narrowly escaped not because the security forces prevented the attacks but because of other reasons, such as inaptitude or pure chance. Thus, Christoph Freiherr von Gersdorff was prepared to blow himself up together with Hitler when inspecting an armory but Hitler left much earlier than anyone predicted. Major-General Henning von Tresckow planted a bomb in Hitler's plane but it did not explode. Colonel Count Stauffenberg put a bomb below the table at a meeting of the General Staff but Hitler was only slightly wounded (while four bystanding general staff officers were killed).

\section{Sweden and Olof Palme}

Olof Palme was a prominent Prime Minister of a well-established and stable democracy, Sweden, with a classical division of power, a strong civil society and a largely homogenous population (except for recent immigrants). The marginal benefits of killing Palme were therefore low. Consequently, an assassination was not seriously considered. In many instances, Palme had no bodyguard protecting him. The marginal cost of killing him was correspondingly low.

Our model predicts a low probability of being killed. The two most important factors contributing to his murder are his prominence and the lack of security measures. His assassination on 28 February 1996 after having visited a cinema came as a total surprise and remains a great mystery to this day (Bondeson 2005, Cooper and Redlinger 2004) ${ }^{20}$. Palme's murder was the first of its kind in modern Swedish history and had an impact across Sweden similar to the assassination of John F. Kennedy in the United States .It may well have been an unpredictable random event possibly by a deranged person ${ }^{21}$. A model based on the desire to change policy is unable to explain this murder. More convincing is a "demand" by a madman attracted by the celebrity status of the Prime Minister.

\footnotetext{
${ }^{19}$ See footnote 6.

${ }^{20}$ More than USD 45 million have been expended, and 700,000 pages written, to investigate the assassination (as of February 25, 2006; "Olof Palme assassination", wikipedia.

${ }^{21}$ It is interesting to note that Swedish politicians seem to share this interpretation. Anna Lindh, the Swedish foreign minister, while shopping in the Ladies department of the Nordiska Kompaniet was stabbed to death in 2003 by Mihjailo Mijailovic who by an appeals court was determined to have suffered from a mental illness at the time of the killing. The attacker does not seem to have been aware that she was a wellknown politician, but much speaks to an interpretation of the attack as a random event (Christensen 2004, Cooper and Redlinger 2004).
} 


\section{United States of America and John F. Kennedy}

American presidents are clearly defined and dominant figures in a well-established democracy with a large number of diverse and aggressive factions. An attacker can be certain of great media attention. These reasons contribute to a significant probability of being assassinated, while the generally extremely tight security measures and the clearly defined succession rules ${ }^{22}$ work in the opposite direction. Four American presidents (Lincoln, Garfield, McKinley and Kennedy) have indeed been assassinated and there is a considerable number of unsuccessful and thwarted attempts ${ }^{23}$. One of the main factors contributing to these many assassination attempts is the dominant position of the American President making him an attractive target.

\section{India and Indira Gandhi}

The daughter of the first Prime Minister of India, Jawaharlal Nehru, Indira Gandhi was a prominent ruler of a newly established democracy with many diverse and aggressive ethnicities and religions. The Indian media are free to report on such events (see Sen 1982, Besley and Burgess 2002). The probability of being the object of an assassination is therefore substantial. Gandhi was well protected but became the victim of the "praetorian effect", namely an assassination by her own security forces. She was murdered on 31 October 1984 in her garden by two of her security guards belonging to a different ethnicity, the Sikhs (Frank 2002, Sarin 1990, Dilip and Ashok 1985).

\section{Switzerland}

All Swiss governments consist of committees of equal persons, in the case of the federal government seven persons, in the cantons between either five or seven persons $^{24}$. Major political decisions are taken via popular referendums, which means that politicians can only take rather unimportant decisions. To kill a politician would have little or no effect because his or her impact on policy is quite small. The country knows a strict division of power and is geographically very decentralized with 26 cantons and over 3,000 communes for a population of 7.5 million. The civil society is intact; trade unions, the churches and private clubs exist in abundance and are independent. According to the model developed, these factors make political assassinations very unlikely. There is only one major factor working in the opposite direction. The country is strongly fractionalized with four official languages and many different dialects. Indeed, the only time there was a fear of attack against politicians was when the French speaking part of the canton Berne wanted to separate. But since the new canton Jura was formed (as a result of several referendums) this threat disappeared. Swiss politicians, including the members of the Bundesrat (the Federal

\footnotetext{
${ }^{22}$ Many people all over the world were much impressed by the quick swearing in as President of Lyndon Johnson already in the plane carrying back Kennedy's corps from Dallas to Washington.

${ }^{23}$ All American presidents since WWII have been subject to assassination attempts (see "The list of United States presidential assassination attempts", wikipedia). ${ }^{24}$ Of the 26 Swiss cantons, 14 have an executive committee of 5, and 12 of 7 members.
} 
Council), normally are not protected and take pride to, for instance, use the train or tram as everyone else. Indeed, no member of the Federal Council has ever been killed for political reasons ${ }^{25}$.

There is, however, one spectacular event when local politicians were murdered in Switzerland. An estranged person who felt unfairly treated by the authorities entered the (totally unprotected) parliament of the small canton of Zug in 2001 and killed three of the seven members of the cantonal council (the executive) as well as 11 members of the 80 member cantonal parliament. These killings had no effect on policy but rather demonstrated that a government by committees and decentralized units are able to deal efficiently even with such horrific incidents. Only half an hour after the attack the government functioned again, not least because the heads of the partly autonomous communes were able to take over.

The five cases are only illustrative and serve to show that a rational choice approach may be useful to better understand political assassinations. The historical cases can, of course, not predict if a particular ruler will be assassinated or not but - in a similar way as econometric studies - can make inferences about the probability of a political assassination happening. The five historical cases discussed suggest that the determinants of the demand side (democracy, prominent ruler, clear succession rule, decentralization, civil society, fractionalization, international engagement, and the media), and on the supply side (extent of security measures) have systematic effects on the likelihood of the ruling politician being attacked .

\section{Policy}

\section{A. Current Policy: Deterrence}

The policies presently undertaken are dominated by a deterrence approach where the costs to the attacker are raised. This is true even for democracies where increasing emphasis has been put on protecting politicians by using secret service, police and even military forces. Thus, for example, the security precautions are huge for the American president, both at home and when he visits foreign countries ${ }^{26}$. It has become common practice in democratic countries to seal off whole streets and even parts of cities to protect local and foreign politicians. The protective measures are even more extensive in authoritarian and dictatorial countries, corresponding to our model's upward shifted marginal cost curve compared to a democracy.

\footnotetext{
${ }^{25}$ There are political assassinations in Switzerland but the victims are foreigners visiting or seeking refuge in the country, and the attackers are also foreigners. Examples are the Austrian Empress and Queen of Hungary Elisabeth ("Sisi" or "Sissi" in books and films) who in 1898 was killed by an anarchist in Lausanne or Kazem Rajavi, an Iranian opposition leader, who was assassinated in 1990 in Geneva. ${ }^{26}$ When the US president visits a foreign country there is a large advance team of secret service agents. When the president arrives he does so with a small air force, a motorcade of armor-plated cars, a communications van packed with state-of -the art devices and 250 heavily-armed secret service agents, dozens of advisers and teams of sniffer dogs. See "Protecting the US president abroad" (http://news.bbc.co.uk/2/hi/amewricas/4535911.stm).
} 
The current emphasis on protective measures can partly be explained by rent seeking (the same can be claimed for the reaction against the terrorist threat, see extensively Frey 2004, chapter 2). There are a great many organizations and persons directly and strongly benefiting from an extension of security measures, in particular the secret service community. The costs of these measures are external to these organizations and persons, and are moreover a public bad so that little opposition is mustered, if any at all. The closing off of streets and parts of cities, for example, creates substantial costs to the population in terms of inconvenience and time lost. For the secret service the costs imposed are irrelevant while the persons negatively affected have no incentive to oppose them at the individual level. A political movement restricting these measures can easily be thwarted as the benefits of the security measures seem so evident.

\section{B. Reducing the Incentives to Assassinate Politicians}

A quite different approach from using deterrence is to reduce the expected benefits for assailants. As suggested in our model, there is a variety of options. The most basic is to acknowledge that political murders are partly, though of course not totally, the result of political oppression. A move to a more democratic regime is bound to reduce the incentives to kill politicians. In other words, being a dictator is - ceteris paribus necessarily connected to a higher danger of being murdered.

Less fundamental measures also serve to reduce the marginal benefits of killing politicians also in democracies:

- The government can be changed from the (democratic) rule of one person (president, prime minister, king) to a committee of several persons. The danger of being attacked would drastically fall if the US executive were to consist in a committee of equals, say of three to seven persons. The incentive to kill any of them would be much smaller as any would-be assassin realizes that killing one of them would not much change policy. The protection of the committee members could be much smaller, and would, say, not exceed much the level given to a normal member of parliament (which in many countries is nil). The proposal to change the American system of government in this way is probably hard to swallow but would, besides the drawbacks, also have other desirable features.

- The decentralization of power can be enhanced by distributing it more equally between the parliament and the courts, and be granting more power to the subunits (states, provinces, communes).

- Care must be taken to preserve and strengthen civil society. Trade unions, religious and the large variety of private organizations can be given farreaching independence, i.e. the law should refrain from interfering in their formation and constitution.

The two first measures require constitutional changes which are sometimes difficult or even impossible to achieve. Thus, a proposal to substitute the position of the American president by a Committee at first seems to be outlandish but it should not be forgotten that even the American constitution has been repeatedly changed. 


\section{Conclusion}

In the course of history a large number of politicians has been assassinated. Even if only rulers, such as presidents, prime ministers, and kings and queens are considered, there are many cases of political murders. They have happened primarily in authoritarian or dictatorial countries, but democracies have also been affected. A rational choice analysis following the economics of crime has been used to distinguish the expected marginal benefits of assassinating a politician, and the marginal cost of attacking a politician. The comparative analysis of various equilibria helps us to gain valuable insights into specific historical events in which politicians were assassinated, and in which there were fewer such attempts.

While an econometric analysis would be desirable, the lack of adequate data prohibits this approach at least for the time being. Exactly in those countries in which our model predicts assassinations to occur most frequently - i.e. in authoritarian and dictatorial countries - the data are either not available at all or of too low quality to engage in serious time series or cross section estimates.

The analysis allows us to draw policy conclusions going beyond the deterrence approach presently dominating. Our analysis suggests that an extension of democracy, a rule by a committee of several politicians, more decentralization via the division of power and federalism, and a strengthening of civil society significantly reduce the incentive to assassinate politicians. It is argued that many of these proposals meet heavy opposition by entrenched rent seeking groups such as the secret service complex. In contrast, the citizens burdened by the deterrence policy due to free-riding problems have little incentive to oppose the deterrence policy, and to engage in bringing about the here suggested policies.

The paper constitutes but a first step towards a more full analysis of political assassinations. Worthwhile future work could be addressed to careful case studies of political assassinations, the use of "analytic narratives" as a method to empirically analyze testable propositions, and the collection of data for at least some aspects of the issues involved.

\section{References}

Adler, Freda, Gerhard O.W. Mueller and William S. Laufer (2006). Criminology. New York: McGraw-Hill.

Alper, Neil O. and Daryl A. Hellman (2006). Economics of Crime: Theory and Practice. New York: Pearson Custom Publishing.

Barkan, Steven E. (2005). Criminology: A Sociological Understanding. Upper Saddle River, NJ: Prentice Hall.

Bates, Robert H., Avner Greif, Margaret Levi, Jean-Laurent Rosenthal and Barry Weingast (1998). Analytic Narratives. Princeton: Princeton University Press.

Becker, Gary S. (1968). Crime and Punishment: An Economic Approach. Journal of Political Economy 76: 497-529.

Becker, Gary S. (1974). Essays in the Economics of Crime and Punishment. New York: National Bureau of Economic Research.

Besley, Tim and Robin Burgess (2002). Land Reform, Poverty Reduction and Growth: Evidence from India. Quarterly Journal of Economics 115: 389-430.

Beyer, Mark (2003). Secret Service. New York: Children's Press 
Bondeson, Jan (2005). Blood on the snow: The killing of Olof Palme. Ithaca: Cornell University Press.

Broszat, Martin (1960). Der Nationalsozialismus. Weltanschauung, Programm und Wirklichkeit. Stuttgart: Deutsche Verlags-Anstalt. Buchanan, James M. (1991). The Economics and Ethics of Constitutional Order. Ann Arbor: University of Michigan Press.

Cameron, Samuel (1988).The Economics of Crime Deterrence: A Survey of Theory and Evidence. Kyklos 41: 301-323.

Christensen, Christian (2004). Political Victims and Media Focus: The Killings of Laurent Kabila, Zoran Djinjic, Anna Lindh and Pim Fortuyn. Journal of Crime, Conflict and the Media 1: 23-40.

CIA (1967). Inspector General's Report on Plots to Assassinate Fidel Castro. CIA Historical Review Program, 23 May 1967.

Cooper, H. H. A. and Lawrence J. Redlinger. (2004). The Murder of Olof Palme: A Tale of Assassination, Deception, and Intrigue. Lewiston, NY: Edwin Mellen Press.

Dafflon, Bernard and Sergio Rossi (1999). Public Accounting Fudges Towards Emu: A First Empirical Survey and Some Public Choice Considerations. Public Choice 101(1-2): 59-84.

Demandt, Alexander (ed) (2000). Das Attentat in der Geschichte. Augsburg: Bechtermünz.

Deriabin, Peter (1984). Watchdogs of Terror: Russian Bodyguards from the Tsars to the Commissars. New Rochelle, NY: Arlington House

Deriabin, Peter and T. H. Bagley (1990). K.G.B.: Masters of the Soviet Union. New York: Hippocrene.

De Witte, Ludo. 2001. The Assassination of Lumumba. London: Verso Books.

DiJulius III, John R. (2003). Secret Service: Hidden Systems that deliver Unforgettable Customer Service. New York: AMACOM.

Dilip, Bobb and Raina Ashok (1985). The Great Betrayal: Assassination of Indira Gandhi. Amsterdam: Stosius Inc.

Downs, Anthony (1957). An Economic Theory of Democracy. New York: Harper and Row.

Duffy, James P. and Vincent L. Ricci (1992). Target Hitler: The Plots to Kill Adolf Hitler. Westpoint, CT: Praeger.

Enders, Walter and Todd Sandler (2006). The Political Economy of Terrorism. Cambridge: Cambridge University Press.

Feierabend, Ivo K., Rosalind L. Feierabend, Betty A. Nesvold, and Franz M. Jaggar. 1971. "Political Violence and Assassination: A Cross-National Assessment." In Assassinations and the Political Order, ed. William J. Crotty. New York:Harper and Row: 54-140.

Fein, Robert A. \& Vossekuil, Brian. (1999). Assassination in the United States: An Operational Study of Recent Assassins, Attackers, and Near Lethal Approachers. Journal of Forensic Sciences, 44: 321-333.

Fest, Joachim C. (1963). Das Gesicht des Dritten Reiches. Munich and Zurich: Piper.

Fetzer, James H. (2000). Experts Speak Out on the Death of John F. Kennedy. Peru, Ill.: Catfeet Press.

Forte, Francesco (2001). The Maastricht "Excessive Deficit" Rules and Creative Accounting. In: Ram Mudambi, Pietro Navarra and Giuseppe Sobbrio (eds). Rules and Reason. Cambridge, UK: Cambridge University Press. 
Frank, Katherine. (2002). Indira: The Life of Indira Nehru Gandhi. New York: Houghton Mifflin.

Freedman, Lawrence Z. (1965). “Assassination: Psychopathology and Social Pathology." Postgraduate Medicine. 37: 650-658.

Frey, Bruno S. (2004). Dealing with Terrorism: Stick of Carrot? Cheltenham, UK: Edward Elgar Publishing.

Frey, Bruno S. (2007). "Overprotected Politicians”. Working Paper 321, Institute for Empirical Research in Economics, University of Zurich.

Gisevius, Hans Bernd (1998). To the Bitter End: An Insider's Account of the Plot to Kill Hitler, 1933-1945. New York: Da Capo Press.

Glaeser, Edward L. (2006). The Political Economy of Warfare. Harvard Institute of Economic Research, Discussion Paper No. 2125.

Graber, G.S. (1982). History of the SS. The Most Terrifying Story of the Century. New York: McKay.

Hamerow, Theodore S. (1997). On the Road to the Wolfs Liar: German Resistance to Hitler. Cambridge: Harvard University Press.

Hoffmann, Peter (1980). Hitler's Personal Security: Protecting the Führer, 1921 1945. New York: Da Capo Press.

Höhne, Heinz (1979). Der Orden unter dem Totenkopf. Die Geschichte der SS. Munich: Bertelsmann.

Hudson, Miles. (2000). Assassination. Thrupp: Sutton Publishing.

Iqbal, Zaryab and Christopher Zorn. (2005). "The Political Consequences of Assassination." Paper prepared for presentation at the Annual Meeting of the Southern Political Science Association, January 4-7, 2006, Atlanta, GA.

Iqbal, Zaryab and Christopher Zorn. (2006). "Sic Semper Tyrannis? Power, Repression, and Assassination Since the Second World War." The Journal of Politics, Vol. 68, No. 3: 489-501.

Jones, Benjamin F. and Benjamin A. Olken. (2006). "Hit or Miss? The Effect of Assassinations on Institutions and War." Mimeo.

Kellerhoff, Sven Felix (2003). Attentäter-Mit einer Kugel die Welt verändern. Köln: Böhlau Verlag.

Kennedy, Daniel B. (2006). A Précis of Suicide Terrorism. Journal of Homeland Security and Emergency Management 3, Issue 4 Article 2.

Kershaw, Ian (2000). Hitler. 1936-1945: Nemesis. London: Allan Lane and Penguin Press.

Laucella, Linda. (1999). Assassination: The Politics of Murder. New York: McGrawHill.

Lentz, Harris M. (1988). Assassinations and Executions: An Encyclopedia of Political Violence, 1865-1986. Jefferson, NC and London: McFarland and Company.

Lentz, Harris M. (2002). Assassinations and Executions: An Encyclopedia of Political Violence, 1900 through 2000. Jefferson, NC: McFarland and Company

Melanson, Philip H. and Peter F. Stevens (2005). The Secret Service: The Hidden History of an Enigmatic Agency. New York: Carroll and Graff.

Nicolle, David (1995). The Janissaries. Oxford, UK: Osprey Publishing.

Reiner, Robert (2002). Media Made Criminality. The Representation of Crime in the Mass Media. Oxford Handbook of Criminology. Oxford: Oxford University Press.

Rodrik, Dani (ed) (2003). In Search of Prosperity. Analytical Narratives on Economic Growth. Princeton: Princeton University Press.

Sarin, Ritu (1990). The Assassination of Indira Gandhi. London: Penguin. 
Schmalleger, Frank (2004). Criminology Today: An Integrative Introduction. Upper Saddle River, NJ: Prentice Hall.

Schumpeter, Joseph A. (1942). Capitalism, Socialism and Democracy. New York: Harper.

Sen, Amartya (1982). Poverty and Famines: An Essay on Entitlements and Deprivation, Oxford: Clarendon Press.

Sifakis, Carl. (2001). Encyclopedia of Assassinations. Rev. Ed. New York: Checkmark Books.

Siegel, Larry J. (2005). Criminology. Toronto: Thomson Wadsworth Publishing.

Siegel, Larry J. (2007). Criminology: The Core. Toronto: Thomson Wadsworth

Statman, Daniel (2004). Targeted Killing. Theoretical Inquiries in Law (Online Edition). (http://www.bepress.com/til/default/vol5/iss1/art7)

Steinert, Marlis (1991). Hitler. Paris: Librairie Arthème Fayard.

Uthmann von, Jörg (2004). Attentat - Mord mit gutem Gewissen. Bern: Siedler.

Von Hagen, Jürgen and Guntram B. Wolff (2004). What Do Deficits Tell Us About Debts? Empirical Evidence on Creative Accounting with Fiscal Rules in the Eu. Series 1: Studies of the Economic Research Centre. Discussion Paper No. 38, Deutsche Bundesbank.

Warren, Earl, et al. (1964). Report of the President's Commission on the Assassination of President John F. Kennedy. Washington: United States Government Printing Office.

Weinstein, Neal D. (1980). Unrealistic Optimism About Future Life Events. Journal of Personality and Social Psychology 39: 806-820.

Wikipedia contributors, “Assassination”, Wikipedia, The Free Encyclopedia, 7 February 2007, 05:57 UTC, <http://en.wikipedia.org/w/index.php?title=Assassination\&oldid=106252030> [accessed 7 February 2007]

Wikipedia contributors, "Bodyguard", Wikipedia, The Free Encyclopedia, 2 February 2007, 11:16 UTC,

<http://en.wikipedia.org/w/index.php?title=Bodyguard\&oldid=105068085> [accessed 7 February 2007]

Wikipedia contributors, "Car bomb", Wikipedia, The Free Encyclopedia, 6 February 2007, 16:31 UTC, <http://en.wikipedia.org/w/index.php?title=Car_bomb\&oldid=106078349> [accessed 7 February 2007]

Wikipedia contributors, "Decolonization", Wikipedia, The Free Encyclopedia, 5 February 2007, 15:19 UTC, $<$ http://en.wikipedia.org/w/index.php?title=Decolonization\&oldid=105807895 $>$ [accessed 7 February 2007]

Wikipedia contributors, "Imperial Guard", Wikipedia, The Free Encyclopedia, 26 January 2007, 19:23 UTC, $<$ http://en.wikipedia.org/w/index.php?title=Imperial_Guard\&oldid=10343937 4> [accessed 7 February 2007]

Wikipedia contributors, "Janissary", Wikipedia, The Free Encyclopedia, 1 February 2007, 15:51 UTC, <http://en.wikipedia.org/w/index.php?title=Janissary\&oldid=104857738> [accessed 7 February 2007]

Wikipedia contributors, "List of assassins", Wikipedia, The Free Encyclopedia, 4 February 2007, 01:39 UTC, 
$<$ http://en.wikipedia.org/w/index.php?title=List_of_assassins\&oldid=1054667

11> [accessed 7 February 2007]

Wikipedia contributors, "List of assassinated people", Wikipedia, The Free

Encyclopedia, 4 February 2007, 08:52 UTC,

$<$ http://en.wikipedia.org/w/index.php?title=List_of_assassinated_people\&oldi $\mathrm{d}=105534439>$ [accessed 7 February 2007]

Wikipedia contributors, "List of people who survived assassination attempts",

Wikipedia, The Free Encyclopedia, 21 January 2007, 20:59 UTC,

$<$ http://en.wikipedia.org/w/index.php?title=List_of_people_who_survived_ass assination_attempts\&oldid=102283544 > [accessed 7 February 2007]

Wikipedia contributors, "List of United States Presidential assassination attempts", Wikipedia, The Free Encyclopedia, 2 February 2007, 20:12 UTC,

<http://en.wikipedia.org/w/index.php?title=List_of_United_States_Presidentia 1_assassination_attempts\&oldid=105167929> [accessed 7 February 2007]

Wikipedia contributors, "List of unsuccessful assassinations", Wikipedia, The Free Encyclopedia, 12 January 2007, 13:20 UTC,

$<$ http://en.wikipedia.org/w/index.php?title=List_of_unsuccessful_assassinatio ns\&oldid=100212829> [accessed 7 February 2007]

Wikipedia contributors, "Olof Palme assassination", Wikipedia, The Free

Encyclopedia, 5 February 2007, 05:55 UTC,

$<$ http://en.wikipedia.org/w/index.php?title=Olof_Palme_assassination\&oldid= 105742081> [accessed 7 February 2007]

Wikipedia contributors, "Praetorian Guard", Wikipedia, The Free Encyclopedia, 27

January 2007, 16:43 UTC,

$<$ http://en.wikipedia.org/w/index.php?title=Praetorian_Guard\&oldid=1036293

94> [accessed 7 February 2007]

Wikipedia contributors, "Royalty and Diplomatic Protection Department", Wikipedia, The Free Encyclopedia, 14 November 2006, 05:03 UTC, $<$ http://en.wikipedia.org/w/index.php?title=Royalty_and_Diplomatic_Protecti on_Department\&oldid $=87700116>$ [accessed 7 February 2007]

Wikipedia contributors, "United States Secret Service", Wikipedia, The Free Encyclopedia, 4 February 2007, 18:29 UTC, <http://en.wikipedia.org/w/index.php?title=United_States_Secret_Service\&ol did=105612496 $>$ [accessed 7 February 2007]

Wilkinson, Doris Y. (1976). Social Structure and Assassination Behavior: The Sociology of Political Murder. Cambridge, MA: Schenkman.

Woolf, Greg (2006). Et tu, Brute? The Murder of Caesar and Political Assassination. London: Profile Books.

Zelizer, Barbie (1992). Covering the Body: The Kennedy Assassination, the Media, and the Shaping of Collective Memory. Chicago: Chicago University Press.

Zussman, Asaf and Noah Zussman (2006). Assassination: Evaluating the Effectiveness of an Israeli Couterterrorism Policy Using Stock Market Data. Journal of Economic Perspectives 20: 193-202. 